\title{
The Challenge of Eliminating Childhood Tuberculosis in Cuba
}

\author{
Gladys Abreu-Suárez MD MS PhD, José A. González-Valdés MD MS, Edilberto González-Ochoa MD PhD, \\ Lourdes Suárez-Álvarez MD
}

\begin{abstract}
WHO's 2015 End Tuberculosis Strategy can succeed only through universal health coverage, social protection, poverty alleviation and effective multisector actions to tackle social determinants in general. The pediatric age group is particularly vulnerable to tuberculosis and historically neglected worldwide. However, this group is a priority within Cuba's National Tuberculosis Control Program that has functioned since 1970, and Cuba is considered a low-incidence country with rates $<7$ per 100,000 population since 2011. Tuberculosis incidence in children aged $<15$ years is $<1$ per 100,000 , similar to that reported in high-income countries and representing less than $2 \%$ of total cases in Cuba. Since 1999, no deaths from tuberculosis, coinfection with HIV or resistance to the two first-line TB drugs have been reported in affected children,
\end{abstract}

\section{INTRODUCTION}

The numbers of people with tuberculosis (TB) and deaths from the disease worldwide are alarming: in 2017, 10 million people developed TB, and the disease caused 1.3 million deaths. Of the total number of people with TB, 1 million were youngsters aged $<15$ years.[1]

The objectives of a post-2015 strategy for ending the TB epidemic were proposed at the World Health Assembly in 2014. WHO's End TB Strategy 2015-2035 set as targets a 95\% reduction in TB deaths by 2035 (compared to 2015) and incidence rates of $<10$ cases per 100,000 population, without catastrophic costs for families. The 2050 target is $<1$ case per million population per year.[2,3]

According to $\mathrm{WHO}$, this ambitious objective can be achieved with existing resources only with universal health coverage, social protection, poverty alleviation and effective multisector actions on social determinants in general.[1]

In Cuba, the National Tuberculosis Control Program (PNCT) has functioned since 1970 and Cuba is considered a low-incidence country ( $<10$ cases per 100,000 population), on track to eliminate TB by 2050 , despite its status as a middle-income, resource-constrained country.[4-6]

Worldwide, the pediatric age group is particularly vulnerable to TB,[6] yet historically has been neglected.[7-10] Thus, children constitute a growing reservoir of TB infection with a high risk of primary TB progression that can, however, be avoided with preventive treatment.[8,10]

IMPORTANCE This article describes Cuba's approach to controlling tuberculosis and proposes further actions to eliminate it, particularly in the pediatric age group. and most diagnosed cases correspond to early, primary forms of the disease. These results place Cuba among the countries on track to eliminate TB by 2050 . This article reviews the pillars and components of the 2015 End TB Strategy and the strategies developed by the National Tuberculosis Control Program that enabled Cuba to bring incidence below the 2035 targets of WHO's End TB strategy. The article also proposes other actions Cuba can take, despite limited resources, to eliminate TB, particularly in the pediatric age group.

KEYWORDS Tuberculosis, communicable disease control, disease control programs, preventive health services, child health, World Health Organization, Cuba
According to $\mathrm{WHO}$, the burden of $\mathrm{TB}$ in children is largely due to the difficulty of making a diagnosis, given the clinical overlap of TB symptoms with other common childhood diseases, and because bacteriologic confirmation is rarely obtained. $[8,10,11]$ This problem is compounded by lack of access to health care and poor quality health services in many countries. It is not strange, therefore, that case definitions between and within countries are inconsistent, with deficient disease recording and reporting practices.[8] Estimates of the burden of childhood TB are usually calculated based on the percentage of children who are ill with the disease compared to the adult population, which is obviously inexact.[3,10]

Child health is a priority in Cuba. The National Maternal Child Health Program has achieved impressive, internationally recognized results, including an infant mortality rate of 4 per 1000 live births and an under- 5 mortality rate of 5.3 per 1000 live births in 2018.[12] TB incidence in children aged $<15$ years represents under $2 \%$ of TB cases (Figure 1), similar to proportions reported in high-income countries. In the USA, TB in children and adolescents accounted for $7 \%$ of cases reported annually between 2008 and 2010;[13] whereas in European Union countries, an average of $4.4 \%$ of TB patients in 2011 were children aged $<15$ years, with a range of $0-11.1 \% \cdot[9,14,15]$

Since 1999, no child with TB in Cuba has died, suffered coinfection with human immunodeficiency virus (HIV), or experienced multidrug resistance (MDR, resistance to the two first-line TB drugs). $[6,12,16]$

This article reviews the main components of the WHO's End TB Strategy and analyzes the strategies developed by the PNCT in this context. Thanks to their implementation, Cuba has already brought incidence below WHO's 2035 target. This paper also examines other actions Cuba can take to eliminate TB, particularly in the pediatric age group.

\section{CUBA AND THE END TB STRATEGY}

WHO's End TB Strategy is composed of four key principles and three pillars with their respective components. The principles are: 
Figure 1: Childhood TB cases, percentage of total cases and incidence rate per 100,000 children aged $<15$ years, Cuba 1980-2017 (selected years)

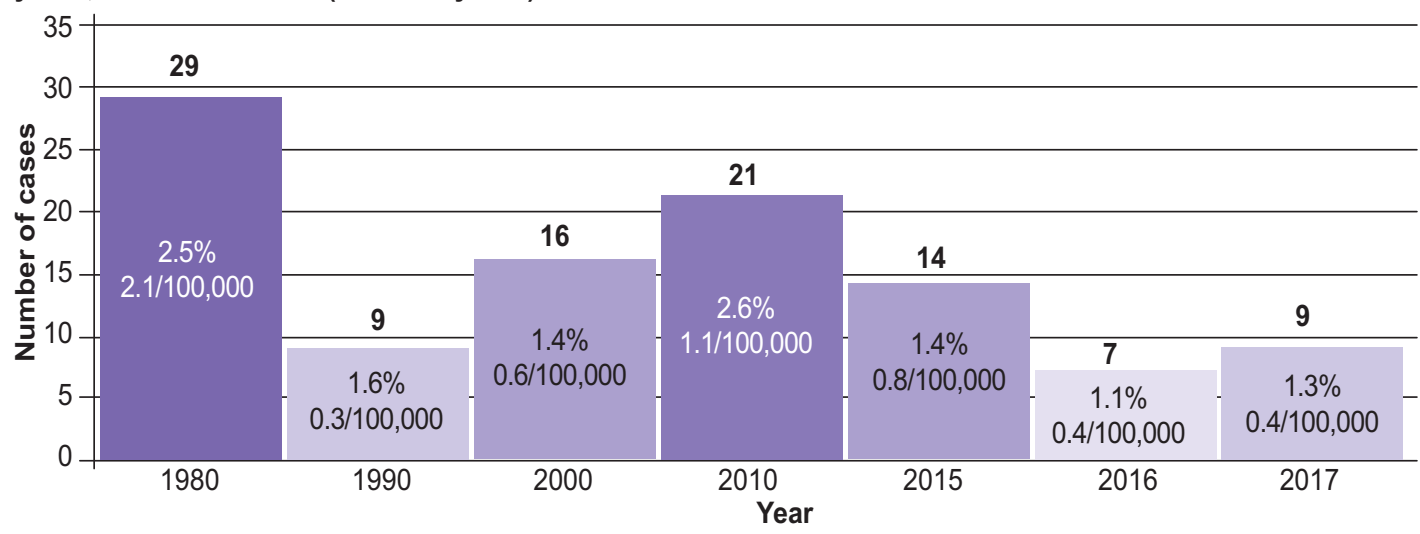

Source: National Medical Records and Health Statistics Bureau, Ministry of Public Health (CU), Annual Statistical Yearbooks, 1980-2017

- government stewardship and accountability, with monitoring and evaluation;

- strong collaboration with civil society and communities;

- protection and promotion of human rights, ethics and equity; and

- adaptation of the strategy and targets in each country, with global collaboration.[2]

Cuba's approach adheres to these principles, although the multisector comprehensive intervention strategy still needs reinforcement.[17,18] Limitations associated with an antiquated housing stock deteriorated by extreme weather events; population growth and aging; internal migration to urban areas; and other local problems still need to be addressed.[16,17]

Pillar 1 The first pillar of the End TB Strategy is patient-centered prevention and care with these key components: early diagnosis; treatment of all people with TB; treatment of people at risk and vaccination against TB; and collaboration between TB and HIV programs, aimed at simultaneously addressing the risks of both diseases.[2]

Early diagnosis[2] As indicated, childhood TB is difficult to diagnose, due in part to low proportion of bacteriologic confirmation $(<50 \%)$. $[8,19]$ The PNCT has achieved $100 \%$ for the process indicator of sample adequacy for diagnostic testing of ill children. Another PNCT process indicator is testing $100 \%$ of contacts of people with TB, regardless of age, which ideally leads to early diagnosis of $90 \%$ of exposed children who develop active TB.[16]

Several requirements of early and efficient identification of patient contacts have not been fully resolved, such as including all frequent contacts within and outside the home, coordinatingwith multisector support-prompt initiation of contact monitoring, and systematic compliance with the four doctor visits indicated for monitoring identified contacts.[6,20] Although the goal of diagnosing at least $85 \%$ of cases has not been met,[16] PNCT actions make possible not only diagnosis of new active TB cases, but also latent TB infection (LTBI). There is a high risk of developing the disease within 2-3 years after becoming infected, especially in children aged $<5$ years. $[7,11,16,21]$

Treating LTBI is a cost-effective strategy that is systematically applied and supervised in children aged $<15$ years, as recommended by WHO.[4,21] In 2003, the Stop TB Initiative created a global working group on childhood TB[8] that recommended creating childhood TB groups in each country. This strategy had been implemented in Cuba eight years earlier.[16]

In Cuba, childhood TB diagnosis and prevention activities are carried out at neighborhood family doctorand-nurse offices (CMFs). These are supervised by a pediatrician at the polyclinic to which the CMF reports (Cuba's primary care system includes two levels, CMFs and polyclinics, which are community-based multispecialty clinics),[22] the municipal epidemiologist and the Provincial Childhood TB Commission (CPTB), the latter comprised of pediatricians from hospital respiratory disease services in each province. Suspected cases are discussed with the National TB Reference Center (CNTB). This approach was implemented in 1995 to strengthen PNCT activities and address the reemergence of TB. $[6,16]$ A systematic effort is made to include each child contact of a TB patient in a CPTB clinical-epidemiologic record, once the child has been assessed in their respective health area, in order to avoid errors detected in operations research, for example: not keeping a record of primary preventive therapy, delayed initiation of contact identification, or failure to conduct all necessary exams (Mantoux test and chest $\mathrm{x}$-ray) in a timely fashion.[20]

The CNTB holds annual workshops with all CPTB heads to review the country's childhood TB situation and incorporate the PNCT's new knowledge and practices. The workshop lays the groundwork for further systematic training of pediatricians and family doctors. Given the country's low incidence rates, medical students have few opportunities to learn firsthand how to evaluate and manage childhood TB cases.[12,23] Instructional activities about TB using CNTB-created materials are offered as student electives, providing additional training, and in 2008, a childhood TB demonstration clinic was added to the 4th year medical school pediatrics rotation. When possible, cases diagnosed in a community health area are used as learning opportunities for doctors and nurses,[24] both as scientific activities and published case reports, respecting confidentiality of personal data.[25]

With the introduction of molecular testing using the Xpert MTB/ RIF assay, priority has been given to rapid positive diagnosis of childhood cases and rapid antibiotic sensitivity tests.[6,24]

Through efforts of the CNTB and its provincial counterparts, in $2013-2017,48$ of 55 diagnosed cases $(87.7 \%)$ were early forms of the disease, none of them serious: 36 primary complexes, 9 cases of adenitis and 3 pleurisies. (Data from the National Medical Records and Health Statistics Bureau, Ministry of Public Health). No deaths in children aged $<15$ years have been reported since 1999.[12,16] 
Treatment of people at risk and vaccination[2] Since 1960, prevention has also involved BCG vaccination of all newborns before discharge from a maternity hospital (99\% of births in Cuba occur in hospitals). In 2018, BCG vaccination coverage was $99.7 \%$.[12]

Treatment of all people with TB[2] In 1984, Cuba adopted the DOTS strategy (directly observed treatment, short course, a shortterm treatment strictly supervised by health personnel). Since 1994, all diagnosed cases are reported and treated, even without microbiological confirmation (the case with most children). In 2014, Cuba updated national PNCT protocols and expanded its norms and procedures pertaining to childhood TB, including diagnostic criteria and treatment monitoring.[4] A single, universal public health system fosters use of standardized intervention protocols.

Drug-resistant cases are few and treated according to their resistance pattern, especially those with MDR (not found in children since 1999). Drug resistance is rare: 20 of 1529 cases in an analysis of the 2009-2010 cohort, mostly isolated isoniazid resistance, with only $6(0.3 \%)$ MDR, contributing to successful treatment.[6,26]

Medications are free for all TB patients, who also receive government-subsidized healthy foods, supplementing basic food rations and other foods purchased. Since 1970, adult patients in the workforce receive their full salary during treatment. Costs to families are minimal, since medical care is government funded and free of charge.[5]

Collaborative TB/HIV activities[2] Cuba's Strategic Plan for the Prevention and Control of STIs and HIVIAIDS includes communitybased health promotion activities, testing and free antiretroviral treatment,[27] operating in close collaboration with the PNCT. Coinfected patients are assessed by teams of experts and complete their treatment at home under supervision.[4,27] Elimination of vertical transmission of HIV in Cuba was WHO-certified in 2015.[18] In 1986-2016, fewer than 200 childhood cases were reported[28] with 8 children aged $<15$ years of a total of 692 cases nationwide $(1.2 \%)$. No cases of coinfection in children aged $<15$ years have been reported since 1999.[29] However, TB/HIV coinfection has increased in the general population, especially in young adults, despite educational efforts. This is a challenge to be overcome, since coinfection threatens the goal of eliminating TB.[6,27]

Pillar 2 The second pillar involves multisector actions, resources and strategic components to implement Pillar 1. A broad social determinants approach to early diagnosis and treatment of all people with TB, including TB/HIV coinfection, demands participation not only of the health sector, but also of other government agencies and civil society organizations.[2]

Pillar 2's components are political commitment guaranteeing adequate resources; universal health coverage; regulatory frameworks for case notification, vital registration, quality and rational use of medicines, and infection control; engagement of communities, civil society organizations, and all public and private care providers; social protection, poverty alleviation, and actions on other TB determinants.[2]

Political commitment, universal health coverage and adequate resources Health care has been a fundamental part of the social transformation begun in Cuba in 1959: a national public health system was established in the early 1960s, providing free, universal, accessible and equitable coverage, later enshrined in the constitution and law.[5,30] This commitment responds to the first principle of the End TB strategy: a national government-led and government-financed program, integrated into all levels of health care, with periodic monitoring and evaluation.[2]

According to 2014-2015 data, Cuba's health budget represents $8.9 \%$ of its national budget (equivalent to $10.4 \%$ of GDP) and covers $94.7 \%$ of health spending.[31] Out-of-pocket health spending is about 5.3\%, the lowest in Latin America.[32] Human resources are guaranteed with training of doctors, nurses, technologists and other allied health workers graduated from Cuban universities, which are also public and tuition free. Cuba has 13 medical sciences universities with 25 medical faculties.[12] In 2017 , there were 84.8 doctors per 10,000 population, working in 450 polyclinics, 150 hospitals (22 of them children's hospitals) and 10,869 family doctor-and-nurse offices distributed throughout the country, including the most remote mountainous regions.[12] There is a decentralized laboratory network for microbiological TB diagnosis throughout the country with municipal laboratories (only bacilloscopy), provincial laboratories (bacilloscopy and cultures), and a national reference laboratory that is a WHO Collaborating Center.[6] In 2018, the diagnostic component was strengthened with the opening of three regional molecular biology laboratories (western, central and eastern) for rapid TB diagnosis,[12] but this activity needs reinforcement at the primary care level.

Eliminating TB is a national priority. The National Action Plan of Cuba's 2016 End TB Strategy proposes, among other goals, speeding up implementation of new diagnostic technology and guaranteeing financial investments to meet the heavy demands of the TB elimination stage.[6] Although Cuba has sought funding support and signed cooperative agreements with other countries, access to costly new technologies needed to bolster the national laboratory network (Xpert, liquid culture media, LED microscopy, etc.) is hampered by the US trade and commercial blockade on Cuba's economy.[6]

Regulatory frameworks for case notification, vital registration, quality and rational use of medicines, and infection control TB case notification has been mandatory since 1962,[5] and all information is received and processed by the Ministry of Public Health's National Medical Records and Health Statistics Bureau. Health statistics have been certified as reliable.[33] Case notification follows $2014 \mathrm{WHO}$ recommendations.[3]

Each birth is registered before the baby is discharged from a maternity hospital.[34] Imported medicines, tuberculin reagents and vaccines are analyzed by Cuba's regulatory agency (the Center for State Control of Medicines and Medical Devices) upon entering the country.[35] When a person with latent or active infection is identified, the health team determines and prescribes full treatment, adjusting the dose to that person's needs, and the family doctor takes charge of administering and monitoring the prescribed treatment.[4]

Engagement of communities, civil society organizations During the 2009-2013 PNCT enhancement project, financed by the Global Fund to Fight AIDS, Tuberculosis and Malaria,[6,18] special attention was given to training facilitators and engaging the public in activities aimed at TB prevention and early detection. Student 
groups in all Cuban universities were trained as facilitators to work at all educational levels and in communities with the highest rates of TB.[36,37] Educational posters and brochures were also distributed, and television spots and documentaries were created and used in community forums. Nevertheless, greater mobilization of social actors is needed, including participation by members of religious groups that provide support to patients' families. Contact tracing also needs to be strengthened to maximize the benefits of prevention and early diagnosis. $[11,16]$

Social protection Social services provide care and subsidies to patients with a variety of social problems that may put them at risk of TB.[32] TB elimination requires improved living conditions, a priority for Cuba's government even in the context of limited resources.[38]

Pillar 3 The third pillar calls for development and rapid uptake of new tools, interventions and strategies, along with research to optimize their impact.[2]

Development and rapid uptake of new tools, interventions and strategies Cuba participates in surveillance of TB drug resistance in the Latin American region[26] and applies internationally established strategies, despite economic obstacles to rapid uptake of new technologies.[4,6] At the November 2017 Congress of the International Union Against Tuberculosis and Lung Disease,
Cuba joined the Ibero-American Network for Infantile TB, formed to highlight the historical neglect of TB in children, describe the problem in country members, and strengthen multicenter collaboration.[39] Cuba is currently part of a comparative study among participating countries to characterize TB in youngsters who were aged $<15$ years in 2013-2017.

Research to optimize implementation and impact, and promote innovation Operations research is conducted at primary, secondary and tertiary care levels on fundamental problems identified in the PNCT, such as efficacy in case detection and guaranteed adherence to treatment, risk factors in the population, associations between TB and other health problems (diabetes, alcoholism, etc.), and use of synthetic indicators to evaluate process quality, among others.[6,35] Recommendations are applied in PNCT updates.[6]

\section{CONCLUSIONS}

PNCT's results, especially in the pediatric age group, show that political will in a context of universal access to health care services at the primary care level can have a major impact on health indicators. These results are the fruit of actions aimed at social protection of populations most vulnerable to TB, with children as top priority, and designed in the framework of the PCNT, which functions despite economic difficulties and makes TB elimination possible in line with the WHO End TB Strategy 2015-2035. - 1/

\section{REFERENCES}

1. World Health Organization. Global Tuberculosis Report 2018 [Internet]. Geneva: World Health Organization; 2018 [cited 2018 Oct 27]. 265 p. Available from: https://www.who.int/tb/publica tions/global_report/en/

2. World Health Organization [Internet]. Geneva World Health Organization; c2019. Health Topics. Tuberculosis. The End TB Strategy; 2019 [cited 2019 Jul 27]. Available from: https://www .who.int/tb/strategy/end-tb/en/

3. World Health Organization. Global Tuberculosis Report 2015 [Internet]. Geneva: World Health Organization; 2015 [cited 2018 Oct 27]. 192 p. Available from: https://apps.who.int/iris/handle/ 10665/191102

4. Ministry of Public Health (CU). Resolución Ministerial 277/2014. Programa Nacional de Control de la Tuberculosis. Manual de normas y procedimientos [Internet]. Havana: Editorial Ciencias Médicas; 2014 [cited 2018 Oct 27]. 201 p. Available from: http://www.sld.cu/galerias/pdf/sitios/ tuberculosis/programa 2015.pdf. Spanish.

5. Beldarraín E. Impact of the 1970 reforms to Cuba's National Tuberculosis Control Program. MEDICC Rev. 2015 Jul;17(3):33-8.

6. González E, Díaz R, Suárez L, Abreu G, Armas L, Beldarraín $E$, et al. Eliminación de la tuberculosis en Cuba: contribuciones recientes, resultados y desafíos. Rev Cubana Med Trop [Internet]. 2017 [cited 2018 Nov 20];69(3) Available from: http://www.revmedtropical.sld .cu/index.php/medtropical/article/view/260/174 Spanish.

7. Khatua S, Geltemeyer AM, Gourishankar A. Tuberculosis: is the landscape changing? Pediatric Res. 2017:81(1). DOI:10.1038/pr.2016.205

8. World Health Organization. The Global Plan to Stop TB 2011-2015 [Internet]. Geneva: World Health Organization; 2010 [cited 2018 Oct 27]. 92 p. Available from: http://www.stoptb.org/assets/ documents/global/plan/TB_GlobalPlanToStop TB2011-2015.pdf
9. Mellado Peña MJ, Santiago García B, BaqueroArtigaoa $F$, Moreno Pérez D, Piñeiro Pérez $R$, Méndez Echevarría $A$, et al. Actualización del tratamiento de la tuberculosis en niños. An Pediatr (Barc) [Internet]. 2018 [cited 2018 Oct 27];88(1):52.e1-52.e12. Available from: https:// doi.org/10.1016/j.anpedi.2017.05.013. Spanish.

10. Caminero JA, Scardigli A. Tuberculosis en niños. Retos y oportunidades. An Pediatr (Barc). 2016;85(6):281-3. Spanish.

11. Carvalhoa I, Golettib D, Manga S, Silva DR Manissero D, Migliori G. Managing latent tuberculosis infection and tuberculosis in children. Pulmonology. 2018 Mar-Apr;24(2):106-14.

12. National Health Statistics and Medical Records Division (CU). Anuario Estadístico de Salud 2018 [Internet]. Havana: Ministry of Public Health (CU); 2019 [cited 2019 May 27]. 206 p. Available from: http://files.sld.cu/bvscuba/files/2019/04/Anuario -Electr\%C3\%B3nico-Espa\%C3\%B1ol-2018 -ed-2019-compressed.pdf. Spanish.

13. Donald PR. The North American contribution to our knowledge of childhood tuberculosis and its epidemiology. Int J Tuberc Lung Dis [Internet] 2014 Aug 1 [cited 2019 May 27];18(8):890-8. Available from: http://dx.doi.org/10.5588/ijtld .13 .0915

14. Erkens CG, de Vries G, Keizer ST, Slump E, van den Hof S. The epidemiology of childhood tuberculosis in the Netherlands: still room for prevention. BMC Infect Dis [Internet]. 2014 May 31 [cited 2019 Feb 20];14:295. Available from: https://bmcinfectdis.biomedcentral.com/articles/ 10.1186/1471-2334-14-295

15. Oesch Nemeth G, Nemeth J, Altpeter E, Ritz N. Epidemiology of childhood tuberculosis in Switzerland between 1996 and 2011. Eur J Pediatr. 2014 Apr;173(4):457-62.

16. Abreu G, González JA, González E, Bouza I, Velázquez A, Pérez T, et al. Cuba's strategy for childhood tuberculosis control, 1995-2005. MEDICC Rev [Internet]. 2011 Jul [cited 2018
Sep 20];13(3):29-34. Available from: http:// www.scielosp.org/scielo.php?script=sci_arttext \&pid=S1555-79602011000300007\&lng=en

17. Monteiro de Andrade LO, Pellegrini Fhilo A, Solar O, Rígoli F, Malagón de Salazar L, CastellFlorit Serrate P, et al. Determinantes sociales de salud, cobertura universal de salud y desarrollo sostenible: estudios de caso en países latinoamericanos. MEDICC Rev [Internet]. 2015 [cited 2018 Sep 20];17(Suppl):S53-61. Available from: http://mediccreview.org/determi nantes-sociales-de-salud-cobertura-universal -de-salud-y-desarrollo-sostenible-estudios-de -caso-en-paises-latinoamericanos/. Spanish.

18. Verdasquera Corcho D, Ramos Valle I, Borroto Gutiérrez S, Rumbaut Castillo R, Pérez Ávila LJ, Alfonso Berrio L, et al. Capacidad de respuesta y desafíos del sistema de salud cubano frente a las enfermedades trasmisibles. Rev Panam Salud Publica [Internet]. 2018 [cited 2018 Oct 27];42:e30. Available from: http://doi .org/10.26633/RPSP.2018.30. Spanish.

19. Graham SM, Cuevas LE, Jean-Philippe $P$, Browning R, Casenghi M, Detjen AK, et al. Clinical case definitions for classification of intrathoracic tuberculosis in children: an update. Clin Infect Dis. 2015 Oct 15;61 Suppl 3:S179-87.

20. Muñoz Peña R, Reynel PGE, Abreu Suárez G, González Valdés JA, Rodríguez Vargas LE. Control de foco de tuberculosis en menores de 15 años. Rev Cubana Pediatr [Internet]. 2014 [cited 2018 Sep 20];86(2). Available from: http:// scielo.sld.cu/scielo.php?script=sci_arttext\&pid =S0034-75312014000200007. Spanish.

21. World Health Organization. Latent tuberculosis infection Updated and consolidated guidelines for programmatic management [Internet]. Geneva: World Health Organization; 2018 [cited 2018 Oct 27]. 64 p. Available from: https://apps.who .int/iris/handle/10665/260233

22. Presno Labrador C. El médico de familia en Cuba. Rev Cubana Med Gen In- 
tegr [Internet]. 2006 Jan-Mar [cited 2019 Jul 13];22(1). Available from: http://scielo.sld .cu/scielo.php?script=sci_arttext\&pid=S0864 $-21252006000100015 \&$ Ing =es. Spanish.

23. Abreu Suárez G, González Valdés JA, Muñoz Peña R, Solar Salaverri LA, Marchena Béquer JJ. La preparación del estudiante de Medicina para la eliminación de la tuberculosis. Educ Med Super [Internet]. 2013 [cited 2013 May 20];27(1). Available from: http://www.ems.sld.cu/index.php/ ems/article/view/113/68. Spanish.

24. Abreu Suárez G. El reto de la tuberculosis infantil. Rev Cubana Pediatr [Internet]. 2016 Jul-Sep [cited 2018 Nov 20];88(3). Available from: http:// revpediatria.sld.cu/index.php/ped/issue/view/4. Spanish.

25. World Medical Association [Internet]. FerneyVoltaire (FR); c2019. Declaración de Helsinki de la AMM -Principios éticos para las investigaciones médicas en seres humanos; [updated 2015 May; cited 2019 Jan 15]. Available from: https:// www.wma.net/es/policies-post/declaracion-de -helsinki-de-la-amm-principios-eticos-para-las -investigaciones-medicas-en-seres-humanos/. Spanish.

26. Lemus D, Echemendía M, Díaz R, Llanes MJ, Suárez L, Marrero A. Antituberculosis drug resistance in pulmonary isolates of Mycobacterium tuberculosis, Cuba 2012-2014. MEDICC Rev [Internet]. 2017 Jan [cited 2018 Oct 27];19(1):10-5. Available from: http://mediccreview.org/antituber culosis-drug-resistance-in-pulmonary-isolates -of-mycobacterium-tuberculosis-cuba-2012-2014/

27. Ministry of Public Health (CU). Plan estratégico nacional para la prevención y el control de las ITS y el VIH/sida. 2014-2018 [Internet]. Havana: Ministry of Public Health (CU); 2013 Dec [cited 2019 Feb 20]. 87 p. Available from: http://files .sld.cu/sida/files/2014/03/pen-primera-parte.pdf. Spanish.

28. ONUSIDA América Latina y el Caribe [Internet] Ciudad de Panamá: ONUSIDA; c2019. Regiones y Países. Cuba: Datos del País 2016; [cited 2019 Feb 21]. Available from: http://onusidalac.org/1/ index.php/internas/item/2324-cuba-new. Spanish.

29. HIV-AIDS Computerized Registry (CU). Situación epidemiológica cierre año 2015 [Internet]. Havana: Ministry of Public Health (CU); 2015 [cited 2019 Feb 22]. Available from: http://files.sld .cu/sida/files/2016/04/ATT00060.ppt. Spanish.

30. Morales Ojeda R, Mas Bermejo P, Castell-Florit $P$, Arocha Mariño C, Valdivia Onega NC, Druyet Castillo D, et al. Transformaciones en el sistema de salud en Cuba y estrategias actuales para su consolidación y sostenibilidad. Rev Panam Salud Publica [Internet]. 2018 Apr [cited 2018 Oct 22];42:e25. Available from: http://do .org/10.26633/RPSP.2018.25. Spanish.

31. Gálvez González AM, González López R, Álvarez Muñiz M, Vidal Ledo MJ, Suárez Lugo NC, Vázquez Santiesteban M. Consideraciones económicas sobre la salud pública cubana y su relación con la salud universal. Rev Panam Salud Publica [Internet]. 2018 [cited 2018 Sep 20];42:e28. Available from: http://do .org/10.26633/RPSP.2018.28. Spanish.

32. Atun R, Monteiro de Andrade LO, Almeida G, Cotlear D, Dmytraczenko T, Frenz P. La reforma de los sistemas de salud y la cobertura universal de salud en América Latina. MEDICC Rev [Internet] 2015 [cited 2018 Sep 20];17(Suppl):S21-39. Available from: http://mediccreview.org/la-refor ma-de-los-sistemas-de-salud-y-la-cobertura -universal-de-salud-en-america-latina/. Spanish.

33. Mathers C, Fat D, Inoue M, Rao C, López A Counting the dead and what they died from: an assessment of the global status of cause of death data. Bull World Health Organization. 2005;83(3).

34. Ministry of Justice (CU). Ley 51 del Registro del Estado Civil [Internet]. 1985 [cited 2019 Feb 17]. Available from: http://files.sld.cu/pre vemi/files/2013/03/ley_51_registro_estado_ci vil_1985.pdf. Spanish.

35. Rojo Pérez N, Valenti Pérez C, Martínez Trujillo $\mathrm{N}$, Morales Suárez I, Martínez Torres E, Fleitas Estévez I, et al. Ciencia e innovación tecnológica en la salud en Cuba: resultados en problemas seleccionados. Rev Panam Salud Publica [Internet]. 2018 Apr [cited 2019 Feb 17];42:e32. Available from: http://doi.org/10.26633/RPSP.2018.32. Spanish.

36. Rojas Hernández N, Larrea Murrell JA, Batista Mainegra A, González Aportela O, Gort Almeida A. Potencialidades del trabajo de extensión universitaria en la prevención de la tuberculosis. Rev Cubana Salud Pública. 2012;38(2):230-7. Spanish.

37. Ruano Martínez D. Realizarán taller de prevención VIH SIDA y Tuberculosis. Emisora Radio Rebelde [Internet]. 2011 Sep 22 [cited 2019 Feb 17]; Ciencia y Salud. Available from: http://www .radiorebelde.cu/noticia/realizaran-taller-preven cion-vih-sida-tuberculosis-20110922/. Spanish.

38. González E, Armas L, Llanes MJ. Progress towards tuberculosis elimination in Cuba. Int J Tuberc Lung Dis. 2007 Apr;11(4):405-11.

39. Rello M. Crean la Red Iberoamericana de Tuberculosis infantil. Milenio Diario S.A. de C.V.
[Internet]]. 2017 Oct 13 [cited 2019 Feb 17]; Estados. Available from: https://www.milenio com/estados/crean-la-red-iberoamericana-de -la-tuberculosis-infantil. Spanish.

\section{THE AUTHORS}

Gladys Abreu-Suárez (Corresponding author: josegv@infomed.sld.cu), pediatrician with a master's degree in comprehensive child health care and a doctorate in medical sciences. Head National Reference Center for Childhood TB; full professor, Medical University of Havana (UCMH), Cuba.

José A. González-Valdés, physician with dual specialties in pediatrics and health administration, and a master's degree in comprehensive child health care; full and consulting professor, UCMH, Havana, Cuba.

Edilberto González-Ochoa, physician specializing in epidemiology with a doctorate in medical sciences. Full and consulting professor, Pedro Kourí Tropical Medicine Institute, Havana, Cuba.

Lourdes Suárez-Álvarez, physician specializing in epidemiology. Coordinator, National Tuberculosis and Respiratory Infection Control Program, Ministry of Public Health, Havana Cuba.

Submitted: January 17, 2019

Approved for publication: August 5, 2019

Disclosures: None 